\title{
Corrigendum: Comprehensive multi-modality assessment of regional and global arterial structure and function in adults born preterm
}

This article has been corrected since Advance Online Publication

Henry Boardman, Katherine Birse, Esther F Davis, Polly Whitworth, Veena Aggarwal, Adam J Lewandowski and Paul Leeson

Hypertension Research (2016) 39, 620; doi:10.1038/hr.2016.36; published online 14 April 2016

Correction to: Hypertension Research (2016) 39, 39-45; doi:10.1038/ hr.2015.102

This article was originally published under a CC BY-NC-ND v4.0 license, but has now been made available under a CC BY 4.0 license. The PDF and HTML versions of the paper have been modified accordingly. cc) (i) This work is licensed under a Creative Commons Attribution 4.0 International License. The images or other third party material in this article are included in the article's Creative Commons license, unless indicated otherwise in the credit line; if the material is not included under the Creative Commons license, users will need to obtain permission from the license holder to reproduce the material. To view a copy of this license, visit http:// creativecommons.org/licenses/by/4.0/ 